\title{
PAXIP1-Associated Glutamate-Rich Protein 1
}

National Cancer Institute

\section{Source}

National Cancer Institute. PAXIP1-Associated Glutamate-Rich Protein 1. NCI Thesaurus. Code C112901.

PAXIP1-associated glutamate-rich protein 1 (254 aa, $28 \mathrm{kDa}$ ) is encoded by the human PAGR1 gene. This protein plays a role in the modulation of both histone methyltransferase activity and gene expression. 